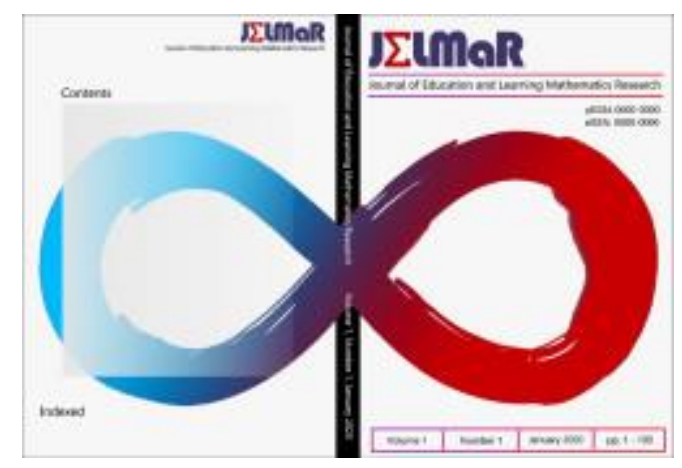

Journal of Education and Learning Mathematics Research (JELMaR)

Online ISSN $\quad:$ 2715-9787

Print ISSN : :2715-8535

Journal Homepage : http://jelmar.wisnuwardhana.ac.id/index.php/jelmar/index

\title{
The Influence Of The Implementation Of Experiential Learning On Mathematics Learning Outcomes At SD Inpres Layang Tua II In Makassar
}

\section{Khaerun Nisa'a Tayibu \& Rahmah Kumullah}

To cite this article: Tayibu, K., \& Kumullah, R. (2021). The Influence Of The Implementation Of Experiential Learning On Mathematics Learning Outcomes At SD Inpres Layang Tua II In Makassar. Journal of Education and Learning Mathematics Research (JELMaR), 2(2), 1-6. https://doi.org/10.37303/jelmar.v2i2.45

To link this article : https://doi.org/10.37303/jelmar.v2i2.45

\section{Publisher}

Department of Mathematics Education,

Faculty of Teacher Training and Education,

Universitas Wisnuwardhana Malang 


\title{
The Influence of The Implementation of Experiential Learning on Mathematics Learning Outcomes at SD Inpres Layang Tua II In Makassar
}

\author{
${ }^{1}$ Khaerun Nisa'a Tayibu, ${ }^{2}$ Rahmah Kumullah \\ Primary Teacher Education Program Study \\ STKIP Andi Matappa \\ Email:icakhaerun@gmail.com
}

\begin{abstract}
This study aims to (1) know the description of the implementation of the experiential learning model in class V SD Inpres Layang Tua II Makassar City, (2) to know the description of the Mathematics learning outcomes of students of SD Inpres Layang Tua II Makassar City, (3) to determine the effect of implementing the experiential model. learning about Mathematics learning outcomes in students of SD Inpres Layang Tua II Makassar City. This type of research is a true experimental research design involving one experimental class and one control class. The research location is in SD Inpres Layang Tua II, Makassar City. The design of this study was a pretest-posttest control group design. The population of this research is the fifth grade students of SD Inpres Layang Tua II Makassar City with a sample of 20 control classes and 20 experimental classes taken randomly. The independent variable in this study is the implementation of the experiential learning model and the dependent variable is the Mathematics learning outcome. Data collection techniques in this study were tests, observation and documentation. The research instrument was a Mathematics learning outcome test with 23 items and a lesson plan (RPP). The data obtained were analyzed by two types of statistics, namely descriptive statistical tests and inferential statistics including: Data Normality Test, Data Homogeneity Test and Hypothesis Test.The results showed that: (i) the application of the experiential learning model in Mathematics learning for fifth grade students of SD Inpres Layang Tua, Makassar City, which consists of concrete experience stages, observation reflection, abstract concepts and applications generally go well, (ii) Mathematics learning outcomes The fifth grade students of SD Inpres Layang Tua II in Makassar City in the pre-test experimental class were lower than the control class with an average score of 47 for the experimental class and 52 for the control class. Meanwhile, in the post-test the experimental class was higher than the control class with an average score. -The experimental class average is 79 and the control class is 70, (iii) there is an effect of the application of the experiential learning model on the Mathematics learning outcomes of class V SD Inpres Layang Tua II Makassar City after hypothesis testing is $0.004<0.05$.
\end{abstract}

Keyword: Experiential Learning Model, Student Learning Outcomes

\section{INTRODUCTION}

Based on Law Number 20 of 2003 concerning the functions and objectives of education in article 3 it reads:

National education has the function of developing capabilities and shaping dignified national character and civilization in order to educate the nation's life, aiming at developing the potential of students to become human beings who believe and fear God Almighty, have noble character, are healthy, knowledgeable, capable, creative, independent, and become a democratic and responsible citizen.

According to (Baharuddin, 2007) there are two factors that influence the success of the learning process. First, factors that come from within the student (internal factors) which include physical condition, intelligence / intelligence, motivation, interests, 
attitudes, and talents. Second, factors that come from outside the student (external factors) which include the school's social environment, community social environment, family social environment, natural environment, teaching methods, curriculum, school discipline and school facilities and infrastructure.

Bruce, Weil and Calhoun (2009) emphasized that the learning model applied in the learning process will have a very important effect on long-term student learning outcomes.

The reality of similar learning conditions also occurs in SD Inpres Layang Tua II Makassar City based on preliminary observations on January 18-26 2016 in class V SD Inpres Layang Tua II Makassar City, the cause is that teachers always dominate the teaching and learning process and the lack of interaction between teachers and students. Most students think that Mathematics lessons are difficult to understand subjects. However, in reality the teacher only delivers material while writing without giving practical work directly in the field. The learning process tends to be active teachers while students are passive and as a result, students' thinking abilities do not develop and this has implications for low student learning outcomes. The results of the observation of the even semester student learning outcomes document data show that classically students are only able to achieve a minimum completeness (KKM) of $69 \%$ classically in grade $\mathrm{V}$ students, which means that these results have not reached the Minimum Completeness Criteria (KKM) in Mathematics subjects which are equal to 74 .

Based on the background described above, the authors are interested in knowing the effect of implementing the experiential learning model on student learning outcomes in class V SD Inpres Layang Tua II, Makassar City. This experiential learning model is expected to be able to improve student learning outcomes. Henceforth, this research is entitled The Effect of the Implementation of the Experiential Learning Model on the Mathematics Learning Outcomes of SD Inpres Layang Tua II in Makassar City.

Based on the background and literature review that has been stated above, the authors take the formulation of the problem as follows:

1. What is the description of the implementation of the experiential learning model in grade V SD Inpres Layang Tua II in Makassar City?

2. What is the description of the Mathematics learning outcomes of SD Inpres Layang Tua II students in Makassar City?

3. Is there an effect of the implementation of the experiential learning model on the Mathematics learning outcomes of Inpres Layang Tua II SD students in Makassar City?

\section{METHOD}

This type of research is an experiment (True Experiment Design). Shape This experimental design the researcher can control for all variables beyond that affect the course of the experiment. Determination of the sample used for experimentation as well as a control group taken randomly from a certain population (Punaji, 2010). This research was conducted at SD Inpres Layang Tua II Makassar City in the odd semester of the 2016/2017 academic year.

The research design used the pretest-posttest control group design method. In this design, Sugiyono stated "that there are two groups, each of which was chosen randomly. The first group was given treatment and the other group was not. The treated group is called the experimental group and the untreated group is called the control group "(Sugiyono, 2012: 76).

The population in this study were all fifth grade students of SD Inpres Layang Tua II Makassar for the 2016/2017 academic year which consisted of two classes totaling 61 
students who were divided into two groups, namely the experimental group and the control group.

According to Sugiyono (2010) the sample is part of the population, for example a population in a certain area, the number of employees in certain organizations, the number of teachers and students in certain schools and so on. In line with this, Sudjana (2005) argues that the sample is partially taken from the population. Therefore, the sample of this study was taken from two classes from class V SD Inpres Layang Tua II Makassar. In this study, there are two variables, namely the independent and the dependent variable. The independent variable is the implementation of the experiential learning model and the dependent variable is the Mathematics learning outcome using the experiential learning model.

The operational definition aims to avoid various interpretations in understanding this research. Therefore, it is necessary to have clarity in the meaning and terms in this research. The implementation of experiential learning is learning that is used to construct student learning experiences by involving students' mental and physical activities where students' concrete experiences, reflections on student learning observations, students' abstract concepts

Data collection was carried out by means of test and documentation techniques. These techniques can be described as follows: Test, observation, and documentation. The instruments used were test learning outcomes and lesson plans. The data analysis technique used is descriptive statistical analysis and inferential statistics. inferential statistics perform normality test, data homogeneity test and data hypothesis testing.

\section{RESULT AND DISCUSSION}

An overview of the Implementation of the Experiential Learning Model in Mathematics Learning in Class V SD Inpres Layang Tua II, Makassar City, namely the performance carried out by the teacher during the action process taking place in Mathematics learning using the experiential learning model in the aspect of teacher activity in each meeting increasing, namely at the first meeting four shortcuts The implementation was in the sufficient category, the second meeting the five syntax carried out were in the sufficient category, the third meeting the eight syntax carried out were in the good category and the fourth meeting of the nine shortcuts that took place were in the good category. The increase in the action of each meeting was supported by the enthusiasm of the students in following the learning process and most students understood every instruction given by the teacher.

Description of Mathematics Learning Outcomes for Class V Students of SD Inpres Layang Tua II, Makassar City :

Table 1. Description of Student Learning Outcomes Before and After being treated

\begin{tabular}{|c|c|c|c|c|c|c|c|c|c|}
\hline \multicolumn{4}{|c|}{ Experiment Group } & \multirow{3}{*}{\multicolumn{2}{|c|}{$\begin{array}{l}\text { Value Classification and } \\
\text { Category }\end{array}$}} & \multicolumn{4}{|c|}{ Control Group } \\
\hline \multicolumn{2}{|c|}{ Pre Test } & \multicolumn{2}{|c|}{ Post Test } & & & \multicolumn{2}{|c|}{ Pre Test } & \multicolumn{2}{|c|}{ Post Test } \\
\hline $\mathrm{F}$ & $\%$ & $\mathrm{~F}$ & $\%$ & & & $\mathrm{~F}$ & $\%$ & $\mathrm{~F}$ & $\%$ \\
\hline 0 & $0 \%$ & 9 & $45 \%$ & $81-100$ & Very Good & 0 & $0 \%$ & 1 & $5 \%$ \\
\hline 5 & $25 \%$ & 10 & $50 \%$ & $61-80$ & Good & 6 & $30 \%$ & 16 & $80 \%$ \\
\hline 5 & $25 \%$ & 1 & $5 \%$ & $41-60$ & Medium & 10 & $50 \%$ & 3 & $15 \%$ \\
\hline 10 & $50 \%$ & 0 & $0 \%$ & $21-40$ & Low & 4 & $20 \%$ & 0 & $0 \%$ \\
\hline 0 & $0 \%$ & 0 & $0 \%$ & $0-20$ & Very Low & 0 & $0 \%$ & 0 & $0 \%$ \\
\hline 20 & $100 \%$ & 20 & $100 \%$ & & & 20 & $\begin{array}{c}100 \\
\%\end{array}$ & 20 & $100 \%$ \\
\hline
\end{tabular}


Description of Mathematics learning outcomes for students Before being given treatment None of the students' pre-test ability in the experimental class was in the very good category, there were 5 students in the good category, there were 5 students in the sufficient category, there were 10 students in the poor category and no pupils in the very poor category. Whereas in the control class there were no students in the very good category, 6 students in the good category, 10 students in the sufficient category, 4 students in the poor category and no students in the very poor category. This indicates that the distribution of data for the experimental and control classes is not much different.

The description of Mathematics learning outcomes in students after being treated with the post-test result value in the experimental class was higher than the pre-test. In the pre-test there were no students in the very poor category, 10 students in the poor category, 5 students in the sufficient category, 5 students in the good category, and no students in the very good category. The mean value of pre-test learning outcomes and post-test learning outcomes has increased, from 47 to 79 . The high score of student learning outcomes on the post-test occurs because the experiential learning model used is able to improve student learning outcomes because students invited to discover and define themselves through direct experience using their senses.

Based on the description above, it can be concluded that the students' pre-test learning outcomes in the experimental class were lower than the control class. Meanwhile, the students' post-test learning outcomes in the experimental class were higher than in the dick class. This shows that using the experiential learning model has a better effect on improving student learning outcomes than the control class that does not use the experiential learning model.

The Effect of the Implementation of the Experiential Learning Model on the Learning Outcomes of Class V Students of SD Inpres Layang Tua II in Makassar City

\section{Table 4.2 Hypothesis Test Results}

\begin{tabular}{|c|c|c|c|c|c|c|}
\hline \multicolumn{7}{|c|}{ Independent Samples Test } \\
\hline & & \multicolumn{2}{|c|}{$\begin{array}{c}\text { Levene's Test for } \\
\text { Equality of } \\
\text { Variances } \\
\end{array}$} & \multicolumn{3}{|c|}{ t-test for Equality of Means } \\
\hline & & $F$ & Sig. & $\mathrm{T}$ & $D f$ & $\begin{array}{c}\text { Sig. } \\
\text { (2-tailed) }\end{array}$ \\
\hline \multirow{2}{*}{$\begin{array}{l}\text { Experiential } \\
\text { Learning }\end{array}$} & Equal variances assumed & 3.119 & .085 & 3.085 & 38 & .004 \\
\hline & Equal variances not assumed & & & 3.085 & 36.532 & .004 \\
\hline
\end{tabular}

It can be seen that the significance value is $<0.05$, namely $0.004<0.05$, so it can be concluded that the posttest value of the experimental class and the posttest value of the control class is significantly different with a significance level of $<0.05$. It can also be seen from the comparison with the $t$ table. The value of $t$ count $>t$ table $(3.085>1.73)$ so it can be concluded that there is a significant difference between the posttest score of the experimental class and the posttest score of the control class or in other words Ho is rejected $\mathrm{H} 1$ is accepted.

\section{CONCLUSION}

Mathematics learning uses the experiential learning model, seen from the performance carried out by the teacher during the action process taking place on the aspect of teacher activity in each meeting increasing, namely at the first meeting the four 
flashes were in the sufficient category, the second meeting the five syntax carried out were in the sufficient category, the third meeting was eight The syntax was in the good category and the fourth meeting of the nine shortcuts that took place was in the good category. Mathematics learning using the experiential learning model can be said to run well because it is supported by the enthusiasm of students in participating in the learning process and most students understand every instruction given by the teacher.

The students' pre-test learning outcomes in the experimental class were lower than the control class with an average score of 47 in the experimental class and 52 in the control class. After applying the experiential learning model, the post-test learning outcomes of students in the experimental class were higher than in the control class with an average The average value in the experimental class is 79 and the control class is 70 . This shows that using the experiential learning model has a better effect on improving student learning outcomes than the control class that does not use the experiential learning model.

The output of the hypothesis test is the significance value $<0.05$, namely $0.004<0.05$, so it can be concluded that the posttest value of the experimental class and the posttest value of the control class is significantly different with a significance level of $<0.05$. It can also be seen from the comparison with the $t$ table. The value of $t$ count $>t$ table (3.085> 1.73) so it can be concluded that there is a significant difference between the posttest score of the experimental class and the posttest score of the control class or in other words Ho is rejected $\mathrm{H} 1$ is accepted.

\section{ACKNOWLEDGMENTS}

The author also expresses gratitude and appreciation to Hj. A. Nurdahliana, S.Pd, as the Principal of SD Inpres Layang Tua II, Makassar City, for his permission to carry out this research in the school being led. Likewise to Mrs. Futriani, S.Pd as the class V teacher, thank you for the direction and guidance that has been given to the author in carrying out the research. All parties that the author did not have the chance to mention one by one who have helped in completing this reseacrh.

\section{REFERENCES}

Alit M, I Made dan Praginda, Wandi. (2009). Hakikat IPA dan Pendidikan IPA untuk Guru SD. Jakarta: Pusat Pengembangan dan Pemberdayaan Pendidik dan Tenaga Kependidikan Ilmu Pengetahuan Alam (PPPPTK IPA) Untuk Program BERMUTU.

Aunurrahman. (2009). Belajar dan Pembelajaran. Pontianak: Alfabeta.

Baharuddin. (2007). Teori Belajar \& Pembelajaran . Jogjakarta: Ar-Ruzz Media.

Bruce, J \& Marsha Weil. (1980). Model of teaching, fifth Edition. USA: Allyn and Bacon A Simon \& Scuster Company.

Bruce, J., Marsha Weil., \& Emily Calhoun. (2009). Model of Teaching: Model-Model Pengajaran. Yogyakarta: Penerbit Pustaka Pelajar.

Coffman, Teresa. (2009). Engaging Students Through Inquiry-Oriented Learning and Technology. USA: Rowman \& Littlefield Education.

Degeng, N.S. (1989). Ilmu Pembelajaran: Taksonomi Variabel. Jakarta: Dirjen Dikti.

Departememen Pendidikan Nasional. (2003). Undang-Undang Nomor 20 Tahun 2003. Tentang Sistem Pendidikan Nasional. Jakarta: Depdiknas.

Endrayanto, Herman Y. Sunu dan Harumurti, Yustiana Wahyu. (2014). Penilaian Belajar di Sekolah. Yogyakarta: PT Kanisius.

Eshach, Haim. (2006). Mathematics Literacy In Primary Schools And Pre-Schools. Netherlands: Springer.

Feasey, Rosemary. (2007). Primary Mathematics for Teaching Assistants. New York: Routledge. 
Gillespie, Helena dan Gillespie, Rob. (2007). Mathematics for Primary School Teachers,. London: Mc Graw-Hill Open University press.

Hamalik, O. (2001). Proses Belajar Mengajar. Jakarta: Bumi Aksara.

Jufri, A. W. (2013). Belajar dan Pembelajaran Sains. Cetakan Pertama. Bandung: Penerbit Pustaka Reka Cipta.

Komalasari, K. (2013). Pembelajaran Kontekstual Konsep dan Aplikasi. Bandung: Refika Aditama.

Kurniasih, I., \& Sani, B. (2014). Sukses Mengimplementasi Kurikulum 2013-Memahami Berbagai Aspek Dalam Kurikulum 2013. Yogyakarta. Penerbit Kata Pena.

Manolas, E. I. (n.d.). Kolb's Experiential Learning Model: Enlivening Physics Course in Primary Education.

Noor, Juliansyah. (2010). Metodelogi Penelitian. Jakarta: Kencana Prenada Media Group.

Peraturan Menteri Pendidikan Nasional Republik Indonesia Nomor 22 Tahun 2006 tentang Standar Isi Untuk Satuan Pendidikan Dasar dan Menengah.

Punaji, Setyosari. (2010). Metode Penelitian Pendidikan dan Pengembangan. Jakarta: kencana.

Purwanto, M. Ngalim. (1998). Psikologi Pendidikan. Jakarta: Remaja Rosdakarya.

Rusman. (2012). Model-Model Pembelajaran, Mengembangkan Profesionalisme Guru. Edisi Kedua. Jakarta: PT Raja Grafindo persada.

Sanjaya, Wina. (2012). Media Komunikasi Pembelajaran. Jakarta: Kencana

Santorock, J. W. (2002). Perkembangan Anak Edisi Kesebelas Jilid 1. Jakarta: Erlangga.

Sardiman. (2003). Interaksi \& Motivasi Belajar Mengajar. Jakarta: PT Raja Grafindo persada.

Slameto. (2003). Belajar dan Faktor-Faktor yang Mempengaruhi. Jakarta : Rineka Cipta.

Standar Kompetensi dan Kompetensi Dasar Tingkat SD/MI. 2006. Departemen Pendidikan Nasional.

Sudaryono. (2012). Dasar-dasar Evaluasi Pembelajaran. Yogyakarta: Graha Ilmu.

Sudjana, Nana.(2005). Penilaian Hasil Proses Belajar Mengajar. Bandung: PT Remaja Rosdakarya.

Sugiyono, (2015). Metode Penelitian Kuantitatif, Kualitatif dan R \& D. Bandung: Alfabeta.

Suprihatiningrum, J. (2013). Strategi Pembelajaran Teori dan Aplikasi. Jogjakarta: Bumi Aksara.

Suyono \& Hariyanto. (2012). Belajar dan Pembelajaran, Teori dan Konsep Dasar. Bandung: Penerbit Remaja Rosdakarya.

Syah, Muhibbin. (2008). Psikologi Pendidikan dengan Pendekatan Baru. Bandung: Remaja Rosdakarya.

Wahap, A.A. (2009). Metode dan Model-Model Mengajar. Cetakan III. Bandung: Penerbit Alfabeta.

Winkel, W.S. (1989). Psikologi Pengajaran. Jakarta: Gramedia. 